\title{
The Converging Pathologies of Obstructive Sleep Apnea and Atrial Arrhythmias
}

\author{
Sana Riaz ${ }^{1}$, Harneet Bhatti ${ }^{1}$, Parth J. Sampat ${ }^{1}$, Amit Dhamoon ${ }^{1}$ \\ 1. Internal Medicine, State University of New York Upstate Medical University, Syracuse, USA
}

Corresponding author: Sana Riaz,riazs@upstate.edu

\begin{abstract}
Obstructive sleep apnea (OSA) is highly prevalent in the United States (US). Along with epidemic rates of obesity, the rate of OSA cases is also on the rise. OSA is associated with multiple chronic health conditions, including hypertension, diabetes, stroke, myocardial ischemia, and heart rhythm disturbances. OSA is commonly treated with continuous positive airway pressure (CPAP) therapy. Several reports indicate that effective treatment of OSA can reduce the risk of cardiovascular diseases, including cardiac arrhythmias, especially atrial fibrillation (AF). CPAP therapy helps to maintain sinus rhythm after interventions such as electrical cardioversion and catheter ablation in patients with AF. However, more data is required to establish a relationship between OSA and other atrial arrhythmias as well to evaluate the effect of CPAP. This review will compile the latest evidence on the pathophysiology, management, and treatment of atrial arrhythmias associated with OSA.
\end{abstract}

Categories: Cardiology, Internal Medicine, Pulmonology

Keywords: obstructive sleep apnea, continuous positive airway pressure, atrial arrhythmia, sudden cardiac death

\section{Introduction And Background}

Obstructive sleep apnea (OSA) is a highly prevalent, yet underdiagnosed, disease in the United States (US) and across the world. OSA is characterized by multiple episodes of partial or complete upper airway collapse during sleep leading to a reduction or complete cessation of airflow. An estimated 15-20 million American adults suffer from OSA, a prevalence comparable to that of diabetes [1]. Approximately $20 \%$ of adults have at least mild OSA, and approximately $7 \%$ of adults have moderate-to-severe OSA. The prevalence of OSA is twice as high in men as in women, and the condition is more prevalent in obese individuals than normalweight individuals [1].

There has been a constant rise in obesity rates in the US over the last several decades. The prevalence of obesity in the US has increased from $30.5 \%$ in $1999-2000$ to $42.4 \%$ in 2017-2018. During the same time period, the prevalence of severe obesity increased from $4.7 \%$ to $9.2 \%$ [2]. A double-digit percent increase, ranging from $14-55 \%$, has also been found in the prevalence of OSA when compared to data from 1988, suggesting a link between obesity and OSA [3]. OSA is associated with many metabolic and physiological consequences such as diabetes, dyslipidemia, and fatty liver disease, along with depression, accidents, headaches, and decreased quality of life $[4,5]$. Additionally, there has been an evolving recognition of the role of OSA in cardiovascular diseases [1]. OSA is associated with hypertension, heart failure, cerebrovascular accidents, myocardial infarction, atrial fibrillation (AF), and sudden cardiac death (SCD) [1].

(๑) Copyright 2020

Riaz et al. This is an open access article distributed under the terms of the Creative Commons Attribution License CC-BY 4.0., which permits unrestricted use, distribution, and reproduction in any medium, provided the original author and source are credited.

The association between sleep apnea and arrhythmias is an emergent issue in cardiology [6]. Cardiac arrhythmias are relatively common and are associated with significant morbidity and mortality. AF is the most common cardiac arrhythmia. It affects an estimated 2.7-6.7 million people in the US. Its impact on healthcare is expected to rise dramatically in the coming decades as the number of cases is projected to rise from 5.6 to 15.9 million by 2050 [7]. The increasing number of people with AF, especially if untreated, can result in a further increase in deleterious health consequences, including heart failure and stroke. The majority of published literature to date focuses on the association between OSA and AF, and insufficient data is available on other atrial arrhythmias. This literature review will provide an overview of the latest evidence on the relationship between the pathophysiology, management, and treatment of OSA and atrial arrhythmias. We will also review the implications of continuous positive airway pressure (CPAP) therapy on patients with AF.

\section{Review}

\section{Obstructive sleep apnea and atrial fibrillation}

AF is the most commonly sustained arrhythmia worldwide and affects nearly 33.5 million people globally [8]. AF is associated with more than 450,000 hospitalizations, and it contributes to more than 150,000 deaths annually [9]. The prevalence of OSA in patients with AF is 21-74\% [10]. Several studies have confirmed the increased incidence of AF in patients with OSA. The Sleep Heart Health Study, which engaged in a comparison between 228 patients with severe OSA and 338 patients without OSA, found that $4.8 \%$ of 
patients with severe OSA had AF, while only $0.9 \%$ of patients without OSA had AF [11]. Additionally, a retrospective study by Gami et al. involving 3,542 patients showed that OSA is a strong predictor of the incidence of AF. The study also concluded that OSA is a strong predictor of AF with a hazard ratio (HR) of 2.18. It was noted that AF occurred in $4.3 \%$ of patients with OSA and $2.1 \%$ of patients without OSA. The study showed that the cumulative probability of AF was significantly higher for subjects who are $<65$ years of age with OSA compared with those without OSA [12]. Similar findings were noted in a more recent metaanalysis study involving a large study population of 19,837, which showed that the odds of having AF was two-fold higher in patients with OSA compared to those without OSA [13]. It has been noted that the risk of AF recurrence after catheter-based pulmonary vein isolation (PVI) is higher in patients with OSA [10,14]. These studies suggest that the prevalence of OSA is significantly higher in patients with AF compared to the general population [15].

\section{Obstructive sleep apnea and other atrial arrhythmias}

Several small observational studies have suggested a positive correlation between OSA and other arrhythmias such as atrioventricular (AV) block, sick sinus syndrome, and other supraventricular tachycardias. One of the largest and earliest studies by Guilleminault et al. assessed 400 patients with severe OSA using polysomnography and 24-hour Holter monitoring. They reported that bradyarrhythmias (i.e., second- or third-degree AV block or sinus pauses of $>2$ seconds) occurred in $18 \%$ of the study population. They also reported atrial tachycardia, paroxysmal AF, and paroxysmal atrial flutter in 7,3 , and $1 \%$ of the study population respectively. There was no control group in their study. They noted that these atrial arrhythmias were only present during sleep and not present when patients were awake, which demonstrates a likely link between OSA and the arrhythmias. In the same study, resolution of sleep time atrial arrhythmias was demonstrated in 50 patients after tracheostomy, suggesting that the arrhythmias were associated with sleep apnea [16]. More recently, an observational study (with no control group) by Becker et al. assessed 239 patients with OSA using polysomnography and 24-hour Holter monitoring and reported that $7.5 \%$ of these patients had significant bradyarrhythmias. Also, they found that the prevalence of bradyarrhythmias correlated strongly with OSA severity and degree of nocturnal desaturations [17].

The increased vagal tone noted with nocturnal hypoxemia increases susceptibility to bradycardic and conduction rhythm disorders in patients with OSA. This seems to occur more frequently during rapid eye movement (REM) sleep and with decreases in oxygen saturation of at least $4 \%$ [18]. Nocturnal hypoxemia, a hallmark of OSA, predicts SCD independently of well-established cardiovascular risk factors, linking SCD with OSA [17,19].

Even though many studies have demonstrated associations between atrial bradyarrhythmias, SCD, and OSA (Table 1), most of these studies were observational studies conducted with small sample sizes. Larger multicentric trials are required to confirm the correlation between OSA and atrial arrhythmias.

\section{Pathophysiology of cardiac arrhythmia and obstructive sleep apnea syndrome}

There are several hypotheses explaining the pathophysiology of cardiac arrhythmias related to OSA. OSA is characterized by a recurrent interruption in ventilation due to repetitive airway collapse, leading to apneic and hypopneic episodes. An apneic event is defined as a 90\% reduction in flow with the presence of respiratory effort for 10 seconds or longer. To be characterized as a hypopneic episode, the following criteria must be met: i) the peak signal excursions drop by $>30 \%$ of pre-event baseline using nasal pressure, positive airway pressure-derived flow, or an alternative hypopnea sensor, ii) the duration of the $>30 \%$ drop in the signal excursion is $>10$ seconds, and iii) there is a $>3 \%$ oxygen desaturation from pre-event baseline or the event is associated with an arousal. Intermittent apneic and hypopneic events lead to arterial desaturations and hypercapnia [20].

OSA is associated with both parasympathetic stimulation during early phases of apnea and sympathetic stimulation in the later phases of apnea; thus, both "vagotonic" and "adrenergic" arrhythmias can be triggered [21]. Hypoxia, through its effect on peripheral chemoreceptors in the carotid body, and hypercapnia, through its effect on the central chemoreceptors, cause increased activation of the sympathetic nervous system. On the other hand, increased intrathoracic negative pressure caused by forced inspiration in response to obstructed airways stimulates the vagus nerve, whereas hypoxemia in the setting of OSA induces the activity of the carotid body. Together, these stimuli can produce a transient increase in parasympathetic activity. The increased vagal tone with nocturnal hypoxemia increases susceptibility to bradycardic and conduction rhythm disorders. Arrhythmias occur more frequently during REM sleep, and with oxygen desaturations of $4 \%$ [18]. Nocturnal hypoxemia also predicts SCD independently of well-established cardiovascular risk factors [17,19], linking SCD with OSA.

In contrast to the idea that an increase in vagal tone in OSA leads to arrhythmias, another hypothesis links the increased sympathetic stimulation seen in OSA in later phases of apnea with these cardiac arrhythmias. Arousal following apneic episodes with re-establishment of respiration through cortical centers causes sympathetic discharge and a decrease in vagal tone, resulting in a marked increase in heart rate [22]. 
Another theory linking atrial arrhythmias to OSA is that increased vascular inflammation associated with OSA may predispose individuals to AF. OSA is associated with higher levels of interleukin-6 (IL-6) and tumor necrosis factor-alpha (TNF- $\alpha$ ), which is thought to create a systemic proinflammatory state [23]. OSA is also known to cause oxidative stress and a state of hypercoagulability [23]. Studies have suggested that inflammation and oxidative stress can be associated with atrial remodeling, which can lead to AF [24].

An additional hypothesis focuses on the changes in intrathoracic pressure in individuals with OSA $[23,25,26]$. Breathing against a collapsed pharyngeal wall can lead to a substantial shift in the intrathoracic pressures which, when transmitted to the atrial chamber, can result in enlargement and can also lead to remodeling of the pulmonary vein ostia. Both of these changes can predispose one to arrhythmias, particularly AF [27].

\section{Management}

Continuous Positive Airway Pressure (CPAP)

The mainstay treatment of AF focuses on rate control, rhythm control, and anticoagulation for the prevention of complications. Despite these treatments, there remains a pressing need for alternative therapies to control AF. Given the association of OSA with AF, theoretically, the treatment of OSA may help with the management of AF. Studies have shown that CPAP may have favorable effects on patients with atrial arrhythmias and OSA by reducing the number of apneic events, thereby leading to increase in oxygen supply, reduction in sympathetic activity, and reduction in the exaggerated shift of intrathoracic pressure, which in turn reduces mechanical stretching and the subsequent electromechanical arrhythmogenic trigger [21]. CPAP therapy is also associated with a decrease in brain natriuretic peptide (BNP) levels, which is an indicator of the decreased cardiac wall stretching. These findings suggest reversibility in the arrhythmogenic substrates induced by OSA by treatment with CPAP [21]. Data from meta-analyses have shown that patients with OSA have a $25-31 \%$ increased risk for AF recurrence after catheter ablation in comparison with patients with no sleep apnea [28]. Another meta-analysis performed by Qureshi et al. [29] and Shukla et al. [28] in 2015 demonstrated reductions in recurrence of AF after CPAP use. In another meta-analysis by Li et al., the risk of recurrence of AF increased from $31 \%$ to $57 \%$ in patients with OSA not undergoing CPAP therapy [30]. It is also noteworthy that CPAP users were found to have the same risk of AF recurrence as patients without OSA [30]. Besides showing reductions in recurrence of AF in CPAP users compared to non-CPAP users, the study by Shukla et al. also demonstrated a similar rate of reductions in AF recurrence in CPAP users following PVI. These results indicated that the relative risk reduction in AF recurrence with CPAP users remained consistent irrespective of whether they were managed medically or with PVI, thereby suggesting the presence of alternate proarrhythmic mechanisms that may be controlled with CPAP use and may remain unchecked with the conventional treatment strategies for AF. These study findings are significant as they provide evidence to the clinician about an additional means to reduce AF recurrence in patients with OSA [29].

Other Treatment Modalities

CPAP is a highly effective treatment option for the management of OSA. However, issues with adherence can limit its efficacy. Compliant regular users are defined as those who meet Centers of Medicare and Medicaid Services (CMS) compliance guidelines (mean positive airway pressure use of $\geqslant 4$ hours per night for more than $70 \%$ of nights). Common reasons for non-adherence are dermatitis, rhinitis, epistaxis, mask leak, aerophagia, barotrauma, and claustrophobia [31]. Based on the literature, the adherence range is $40-85 \%$, which has persuaded healthcare professionals to explore alternative therapies for the management of OSA [31]. Upper airway stimulation, especially hypoglossal nerve stimulation, is a new and alternative therapy for patients with OSA who cannot tolerate CPAP therapy. Oral appliances such as tongue-retaining devices and mandibular advancement devices or surgical interventions have been used in patients who cannot tolerate or do not wish to utilize CPAP. Surgical options for OSA include tonsillectomy and nasal or palatal surgeries [32]. Weight-loss is another option since there is evidence of prevention and reduction of AF burden through aggressive risk-factor modifications [15].

Table 1 summarizes the studies showing the correlation between OSA and atrial arrhythmias. Based on the latest literature, CPAP has shown to be the most effective intervention to decrease the recurrence of atrial arrhythmias in patients with OSA (Table 2). However, more data is required to evaluate the therapeutic role of other options, as mentioned above, in the management of OSA and atrial arrhythmias.

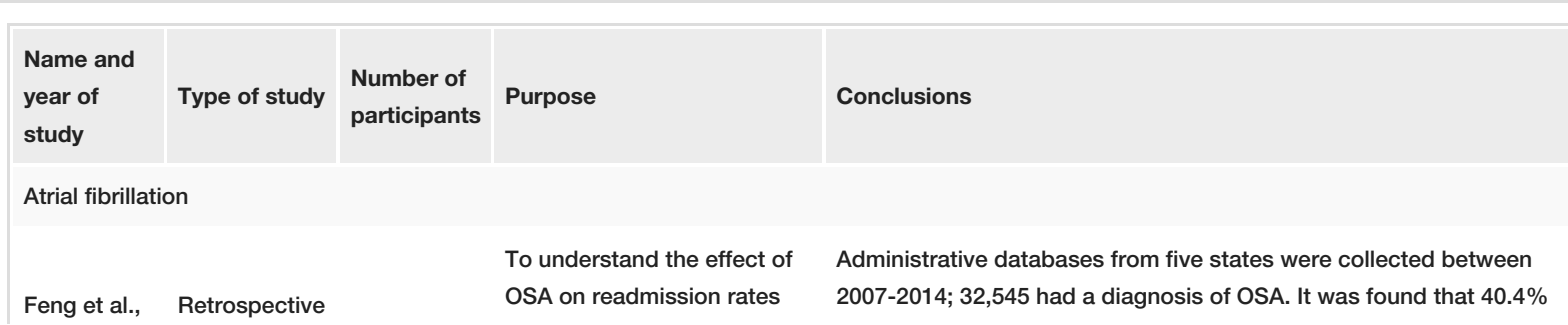




\section{Cureus}

\begin{tabular}{|c|c|c|c|c|}
\hline 2019 [33] & study & 506,604 & $\begin{array}{l}\text { and postoperative AF in } \\
\text { patients following cardiac } \\
\text { surgery }\end{array}$ & $\begin{array}{l}\text { with OSA developed AF compared to } 35.8 \% \text { without a diagnosis of } \\
\text { OSA ( } p<0.001) \text {. Participants with OSA were also noted to have high } \\
30 \text { - and } 90 \text {-day readmission rates }\end{array}$ \\
\hline $\begin{array}{l}\text { Youssef et } \\
\text { al., 2018 } \\
\text { [13] }\end{array}$ & Meta-analysis & 19,837 & $\begin{array}{l}\text { To assess the relationship } \\
\text { between OSA and the risk of } \\
\text { AF }\end{array}$ & $\begin{array}{l}\text { The analysis was conducted using nine studies. The control group } \\
\text { included } 7,582 \text { subjects, and the OSA group included } 12,255 \\
\text { subjects. The risk of AF was found to be higher among OSA versus } \\
\text { the control group (OR: } 2.120,95 \% \text { Cl: } 1.845-2.436, Z ; 10.598 \text {; } \\
\text { p }<0.001 \text { ) }\end{array}$ \\
\hline $\begin{array}{l}\text { Holmqvist } \\
\text { et al., } 2015 \\
\text { [34] }\end{array}$ & Observational & 10,132 & $\begin{array}{l}\text { To determine if patients with } \\
\text { OSA have a higher likelihood } \\
\text { of progressing to more } \\
\text { persistent forms of AF or } \\
\text { required more } \\
\text { hospitalizations and/or have } \\
\text { worse outcomes compared } \\
\text { to patients without OSA }\end{array}$ & $\begin{array}{l}\text { It was noted that patients with OSA had a higher risk of } \\
\text { hospitalization ( } 43 \text { vs. } 35 \text { events } / 100 \text { patient-years, } p=0.0078 \text { ), but } \\
\text { similar rates of mortality, AF progression, and major adverse } \\
\text { cardiovascular events as patients without OSA }\end{array}$ \\
\hline $\begin{array}{l}\text { Ng et al., } \\
2011 \text { [35] }\end{array}$ & Meta-analysis & 3,995 & $\begin{array}{l}\text { To investigate the role of } \\
\text { OSA on AF recurrence after } \\
\text { catheter-based pulmonary } \\
\text { vein isolation }\end{array}$ & $\begin{array}{l}\text { Patients with OSA have a } 25 \% \text { greater risk of } \mathrm{AF} \text { recurrence after } \\
\text { catheter ablation than those without OSA (risk ratio: } 1.25,95 \% \mathrm{Cl} \text { : } \\
1.08-1.45, p=0.003 \text { ) }\end{array}$ \\
\hline $\begin{array}{l}\text { Gami et al., } \\
2007 \text { [12] }\end{array}$ & $\begin{array}{l}\text { Retrospective } \\
\text { cohort study }\end{array}$ & 3,542 & $\begin{array}{l}\text { To identify obesity and OSA } \\
\text { as independent predictors of } \\
\text { incidence of atrial } \\
\text { fibrillation/flutter }\end{array}$ & $\begin{array}{l}\text { AF occurred in } 114 \text { of } 2,626 \text { patients ( } 4.3 \% \text { ) with OSA and } 19 \text { of } 916 \\
\text { patients }(2.1 \% \text { ) without OSA. OSA (defined by an AHI of 5) was a } \\
\text { strong predictor of incident AF (HR: } 2.18,95 \% \text { Cl: } 1.34-3.54 \text {, } \\
\text { p=0.002). It was also noted that the severity of OSA was associated } \\
\text { with a higher incidence of AF. The study also indicated that the } \\
\text { cumulative probability of incident AF was significantly higher in } \\
\text { subjects of <65 years of age with OSA compared with those without } \\
\text { OSA }\end{array}$ \\
\hline $\begin{array}{l}\text { Mehra et } \\
\text { al., } 2006 \\
{[11]}\end{array}$ & $\begin{array}{l}\text { Longitudinal } \\
\text { cohort }\end{array}$ & 566 & $\begin{array}{l}\text { To determine the prevalence } \\
\text { of nocturnal cardiac } \\
\text { arrhythmias in sleep- } \\
\text { disordered breathing } \\
\text { patients }\end{array}$ & $\begin{array}{l}\text { The study involved } 228 \text { patients with OSA and } 338 \text { patients without } \\
\text { OSA. AF had a prevalence of } 4.8 \% \text { in the study population. It was } \\
\text { determined that patients with severe OSA would have a two-to-four- } \\
\text { fold higher chance of developing complex arrhythmias }\end{array}$ \\
\hline $\begin{array}{l}\text { Gami et al., } \\
2004 \text { [15] }\end{array}$ & $\begin{array}{l}\text { Prospective, } \\
\text { cross- } \\
\text { sectional }\end{array}$ & 524 & $\begin{array}{l}\text { To determine the prevalence } \\
\text { of OSA in AF patients }\end{array}$ & $\begin{array}{l}\text { This study involved } 151 \text { patients with AF and } 312 \text { patients with } \\
\text { another cardiovascular disease. The prevalence of OSA was higher } \\
\text { in patients with AF than in the opposing group. The adjusted OR } \\
\text { was } 2.19\end{array}$ \\
\hline $\begin{array}{l}\text { Porthan et } \\
\text { al., 2004 } \\
\text { [36] }\end{array}$ & Case-control & 115 & $\begin{array}{l}\text { To determine the prevalence } \\
\text { of arrhythmias in OSA } \\
\text { patients }\end{array}$ & $\begin{array}{l}\text { OSA was common in AF patients. However, the study could not } \\
\text { demonstrate that OSA was more common in AF patients than in the } \\
\text { corresponding controls }\end{array}$ \\
\hline $\begin{array}{l}\text { Javaheri et } \\
\text { al., } 1998 \\
{[37]}\end{array}$ & Prospective & 81 & $\begin{array}{l}\text { To determine the prevalence } \\
\text { of arrhythmias in OSA } \\
\text { patients }\end{array}$ & $\begin{array}{l}\text { All patients were male, with stable heart failure and left ventricular } \\
\text { ejection fraction (LVEF) of }<45 \% \text {. The prevalence of AF was } 22 \% \\
\text { versus } 5 \% \text { ( } p=0.026) \text { in this study population }\end{array}$ \\
\hline $\begin{array}{l}\text { Flemons et } \\
\text { al., } 1993 \\
\text { [38] }\end{array}$ & Prospective & 263 & $\begin{array}{l}\text { To determine the prevalence } \\
\text { of arrhythmias in OSA } \\
\text { patients }\end{array}$ & $\begin{array}{l}\text { Patients with sleep apnea were found to have a low prevalence of } \\
\text { arrhythmias. There was a } 1.3 \% \text { prevalence of complex ventricular } \\
\text { ectopy, a } 2.6 \% \text { prevalence of frequent ventricular premature beats, } \\
1.3 \% \text { prevalence of second-degree AV block, and a } 5.2 \% \\
\text { prevalence of sinus arrest }\end{array}$ \\
\hline \multicolumn{5}{|c|}{ Sick sinus syndrome } \\
\hline $\begin{array}{l}\text { Koehler et } \\
\text { al., } 1997 \\
{[18]}\end{array}$ & Prospective & 16 & $\begin{array}{l}\text { To determine the correlation } \\
\text { between sleep stage, } \\
\text { oxygen desaturation, and } \\
\text { apnea-associated } \\
\text { bradyarrhythmias as well as } \\
\text { to assess the effect of } \\
\text { treatment with CPAP }\end{array}$ & $\begin{array}{l}\text { During rapid eye movement (REM) sleep, the frequency of heart } \\
\text { block was higher than during non-REM sleep ( } 87.9 \% \text { compared to } \\
12.1 \text {; it was noted to be statistically significant); } 93.5 \% \text { of } \\
\text { bradyarrhythmias occurred with desaturation of at least } 4 \% \text {. With } \\
\text { CPAP/bilevel positive airway pressure (BiPAP) therapy, } \\
\text { apnea/hypopnea index (AHI) decreased from } 75.5 \pm 39.6 \cdot h-1 \text { to } 3.0 \\
\pm 6.6 \cdot h-1 \text { ( }<<0.01 \text { ) }\end{array}$ \\
\hline Simantirakis & & & To determine the prevalence & $\begin{array}{l}\text { Twenty-three patients were studied using a loop recorder; } 47 \% \text { of } \\
\text { these untreated patients had nocturnal bradyarrhythmias. On the }\end{array}$ \\
\hline
\end{tabular}




\section{Cureus}

\begin{tabular}{|c|c|c|c|c|}
\hline $\begin{array}{l}\text { et al., } 2004 \\
{[39]}\end{array}$ & Longitudinal & 23 & $\begin{array}{l}\text { of arrhythmias in OSA } \\
\text { patients }\end{array}$ & $\begin{array}{l}\text { contrary, bradyarrhythmias were noted in only } 13 \% \text { of the patients } \\
\text { on a } 48 \text {-hour Holter monitor }\end{array}$ \\
\hline $\begin{array}{l}\text { Garrigue et } \\
\text { al., 2007 } \\
\text { [40] }\end{array}$ & Observational & 98 & $\begin{array}{l}\text { To determine the prevalence } \\
\text { of sleep apnea syndrome } \\
\text { (SSA) in pacemaker patients }\end{array}$ & $\begin{array}{l}\text { The overall prevalence of sleep apnea syndrome (SAS) was } 59 \% \text { in } \\
\text { pacemaker patients. In patients with sinus node dysfunction, } 58 \% \\
\text { were noted to have clinically silent SAS, and } 27 \% \text { had severe SAS } \\
\text { (AHI: >30/hour) }\end{array}$ \\
\hline $\begin{array}{l}\text { Steiner et } \\
\text { al., } 2008 \\
{[41]}\end{array}$ & Observational & 12 & $\begin{array}{l}\text { To understand the } \\
\text { relationship between sleep } \\
\text { apnea and sinus } \\
\text { abnormalities }\end{array}$ & $\begin{array}{l}\text { The study included patients with symptomatic heart failure (New } \\
\text { York Heart Association class II-III). There was no correlation noted } \\
\text { between mild sleep apnea and sinus abnormalities }\end{array}$ \\
\hline \multicolumn{5}{|c|}{ Atrioventricular block } \\
\hline $\begin{array}{l}\text { Becker et } \\
\text { al., } 1998 \\
{[17]}\end{array}$ & Observational & 239 & $\begin{array}{l}\text { To determine the prevalence } \\
\text { of heart block in patients } \\
\text { with sleep apnea }\end{array}$ & $\begin{array}{l}\text { It was reported that } 7.5 \% \text { of patients had significant } \\
\text { bradyarrhythmias (i.e., second- or third-degree AV block or sinus } \\
\text { pauses of }>2 \text { seconds). Also, it was noted that the prevalence of } \\
\text { bradyarrhythmias correlated strongly with OSA severity and degree } \\
\text { of nocturnal desaturation, such that all patients with significant } \\
\text { bradyarrhythmias had an AHI } 60 / \mathrm{h} \text { or more (accounting for } 20 \% \text { of } \\
\text { this subgroup of patients) }\end{array}$ \\
\hline \multicolumn{5}{|c|}{ Sudden cardiac death } \\
\hline $\begin{array}{l}\text { Gami et al., } \\
2013[19]\end{array}$ & $\begin{array}{l}\text { Prospective, } \\
\text { longitudinal }\end{array}$ & 10,701 & $\begin{array}{l}\text { To determine if there is an } \\
\text { association between SCD } \\
\text { and OSA }\end{array}$ & $\begin{array}{l}\text { SCD was best predicted by age of }>60 \text { years (HR: } 5.53 \text { ), AHI of }>20 \\
\text { (HR: } 1.60 \text { ), mean nocturnal oxygen saturation of }<93 \% \text { (HR: } 2.93 \text { ) } \\
\text { and lowest mean nocturnal oxygen saturation of }<78 \% \text { (HR: } 2.60 \text { ) (all } \\
p<0.0001 \text { ) }\end{array}$ \\
\hline $\begin{array}{l}\text { Gami et al., } \\
2005 \text { [42] }\end{array}$ & Retrospective & 112 & $\begin{array}{l}\text { To determine the rate of } \\
\text { sudden death in OSA }\end{array}$ & $\begin{array}{l}\text { People with sudden death from cardiac causes from midnight to } 6 \\
\text { a.m. had a significantly higher AHI than those with sudden death } \\
\text { from cardiac causes during other time intervals. The relative risk of } \\
\text { sudden death from cardiac causes between midnight to } 6 \text { a.m. in } \\
\text { patients with OSA was } 2.57 \text { (95\% Cl: } 1.87-3.52 \text { ) }\end{array}$ \\
\hline
\end{tabular}

\section{TABLE 1: Studies showing the correlation between OSA and atrial arrhythmias}

OSA: obstructive sleep apnea; AF: atrial fibrillation; Cl: confidence interval; HR: hazard ratio; CPAP: continuous positive airway pressure; BiPAP: bilevel positive airway pressure; AHI: apnea-hypopnea index; SAS: sleep apnea syndrome; SCD: sudden cardiac death; AV: atrioventricular; OR: odds ratio; LVEF: left ventricular ejection fraction 


\section{Cureus}

\begin{tabular}{|c|c|c|c|}
\hline $\begin{array}{l}\text { Name and } \\
\text { year of } \\
\text { study }\end{array}$ & Type of study & $\begin{array}{l}\text { Number of } \\
\text { participants }\end{array}$ & Conclusions \\
\hline $\begin{array}{l}\text { Becker et } \\
\text { al., } 1995 \\
\text { [43] }\end{array}$ & Observational & 239 & $\begin{array}{l}17 \text { of the } 239 \text { patients with OSA were noted to develop heart block }(7.1 \%) \text {. Following treatment with } \\
\text { CPAP, AV block and sinus arrest were eliminated in } 12 \text { of the } 17 \text { patients. Episodes were reduced in } \\
\text { another three patients. One patient continued to have increased frequency of sinus arrest after four } \\
\text { weeks of CPAP treatment }\end{array}$ \\
\hline $\begin{array}{l}\text { Harbison et } \\
\text { al., } 2000 \\
\text { [44] }\end{array}$ & $\begin{array}{l}\text { Prospective, } \\
\text { cross- } \\
\text { sectional }\end{array}$ & 45 & $\begin{array}{l}\text { In this study, only eight patients }(18 \%) \text { demonstrated pathologically significant rhythm disturbances. } \\
\text { Recurring sinus pauses during sleep were the most common dysrhythmia (six patients), lasting } 10 \\
\text { seconds. One patient also developed an episode of a variable second-degree AV block lasting } 4.5 \\
\text { minutes. The resolution of rhythm disturbances was noted in seven out of eight patients following } \\
\text { treatment with CPAP. Additionally, the resolution of non-significant rhythm disturbances was also } \\
\text { noted with CPAP }\end{array}$ \\
\hline $\begin{array}{l}\text { Kanagala et } \\
\text { al., } 2003 \\
\text { [45] }\end{array}$ & Observational & 43 & $\begin{array}{l}\text { The recurrence of AF one year after electrical cardioversion was compared between patients with } \\
\text { treated and untreated OSA. Maintenance of sinus rhythm was strongly associated with CPAP use, } \\
\text { and only } 42 \% \text { of the treated patients had recurrent AF, compared with } 82 \% \text { of untreated patients }\end{array}$ \\
\hline $\begin{array}{l}\text { Simantirakis } \\
\text { et al., } 2004 \\
\text { [39] }\end{array}$ & Longitudinal & 23 & $\begin{array}{l}\text { Eight weeks after initiation of treatment with CPAP, the total number of bradyarrhythmias tended to } \\
\text { decrease. Six months after treatment, there was only one patient with bradycardias and one with } \\
\text { pauses. No pauses were detected after the six-month time point and no bradycardias after the 10- } \\
\text { month time point }\end{array}$ \\
\hline $\begin{array}{l}\text { Marin et al., } \\
2005 \text { [46] }\end{array}$ & $\begin{array}{l}\text { Prospective, } \\
\text { cohort }\end{array}$ & 1651 & $\begin{array}{l}\text { Patients with the severe untreated disease had a higher incidence of fatal cardiovascular events } \\
\text { ( } 1.06 \text { per } 100 \text { person-years) and non-fatal cardiovascular events }(2 \cdot 13 \text { per } 100 \text { person-years }) \\
\text { compared to untreated patients with the mild-moderate disease }(0.55, p=0.02 ; 0.89, p<0.0001) \text {, } \\
\text { simple snorers }(0.34, p=0.0006 ; 0.58, p<0.0001) \text {, patients treated with CPAP }(0.35, p=0.0008 ; 0.64 \text {, } \\
p<0.0001) \text {, and healthy participants }(0.3, p=0.0012 ; 0.45, p<0.0001)\end{array}$ \\
\hline $\begin{array}{l}\text { Li et al., } \\
2014 \text { [30] }\end{array}$ & $\begin{array}{l}\text { Meta- } \\
\text { analysis }\end{array}$ & 2,851 & $\begin{array}{l}\text { Patients with OSA had a } 31 \% \text { greater risk of AF recurrence after successful catheter ablation } \\
\text { compared to non-OSA patients (relative risk: } 1.31, p=0.00) \text {. The risk of AF recurrence increased by } \\
57 \% \text { in patients who did not undergo CPAP therapy (OSA-CPAP patients) (relative risk: } 1.57 \text {, } \\
p=0.00 \text { ); however, patients who underwent CPAP therapy (OSA + CPAP) had a risk of AF recurrence } \\
\text { similar to that of the non-OSA patients (relative risk: } 1.25, p=0.59 \text { ) }\end{array}$ \\
\hline $\begin{array}{l}\text { Qureshi et } \\
\text { al., } 2015 \\
\text { [29] }\end{array}$ & $\begin{array}{l}\text { Meta- } \\
\text { analysis }\end{array}$ & 4,516 & $\begin{array}{l}\text { Eight studies published between } 2003-2013 \text { were included in the meta-analysis; } 4,516 \text { participants } \\
\text { with AF underwent cardiac ablation, and out of these, } 1,247 \text { were diagnosed with OSA, and } 698 \\
\text { were treated with CPAP. The study showed that the use of CPAP was associated with a } 44 \% \\
\text { decreased risk of recurrence of AF (pooled relative risk: } 0.56 ; 95 \% \text { Cl: } 0.47-0.68 ; p<0.001 \text { ) }\end{array}$ \\
\hline $\begin{array}{l}\text { Holmqvist } \\
\text { et al., } 2015 \\
\text { [34] }\end{array}$ & Observational & 10,132 & $\begin{array}{l}\text { No major differences in hospitalization or cardiovascular outcomes were observed between } \\
\text { patients with OSA with or without CPAP treatment; however, AF progression was less common in } \\
\text { patients treated with CPAP }\end{array}$ \\
\hline $\begin{array}{l}\text { Shukla et } \\
\text { al., } 2015 \\
\text { [28] }\end{array}$ & $\begin{array}{l}\text { Meta- } \\
\text { analysis }\end{array}$ & 1,087 & $\begin{array}{l}\text { Seven observational studies were incorporated. It was noted that users of CPAP had a significant } \\
\text { reduction in AF recurrence rate compared with nonusers [ } \mathrm{n}=186 \text { of } 557(33.3 \%) \text { vs. } 308 \text { of } 530 \\
\text { ( } 58.1 \%) \text {; relative risk: } 0.58 ; 95 \% \mathrm{Cl}: 0.51-0.67 ; \mathrm{p}<0.001] \text {. Additionally, In patients who underwent PVI, } \\
\text { users of CPAP were found to have a lower risk of AF recurrence in comparison with nonusers [n = } \\
173 \text { of } 518(33.3 \%) \text { vs. } 273 \text { of } 474(57.6 \%) \text {; relative risk: } 0.58 ; 95 \% \mathrm{Cl}: 0.50-0.67 ; \mathrm{p}<0.001]\end{array}$ \\
\hline $\begin{array}{l}\text { Wu et al., } \\
2016[47]\end{array}$ & Observational & 72 & $\begin{array}{l}\text { CPAP therapy resulted in a significant decrease in the average number of episodes of heart block, } \\
\text { from } 148.58 \pm 379.44 \text { to } 16.07 \pm 58.52\end{array}$ \\
\hline
\end{tabular}

\section{TABLE 2: Studies showing the effect of CPAP on patients with atrial arrhythmias and OSA}

OSA: obstructive sleep apnea; AF: atrial fibrillation; Cl: confidence interval; CPAP: continuous positive airway pressure; AV: atrioventricular

\section{Conclusions}

Many studies have demonstrated a correlation between OSA and decreased recurrence of AF with CPAP therapy, providing strong evidence that patients with OSA may be at a higher risk of AF and that treatment of OSA may help manage AF in this population. However, there is insufficient data available regarding the association between other atrial arrhythmias and OSA. Most published studies demonstrating a correlation between OSA, atrial arrhythmias, and CPAP therapy are primarily observational studies performed on small 
study populations. Large randomized clinical trials are needed to further endorse and confirm the relationship between OSA and atrial arrhythmias and the effects of CPAP use. Furthermore, additional randomized clinical trials are required to evaluate the benefit of other treatment modalities, such as autonomic nervous system modulation and risk-factor modifications, in patients with OSA and arrhythmias.

\section{Additional Information \\ Disclosures}

Conflicts of interest: In compliance with the ICMJE uniform disclosure form, all authors declare the following: Payment/services info: All authors have declared that no financial support was received from any organization for the submitted work. Financial relationships: All authors have declared that they have no financial relationships at present or within the previous three years with any organizations that might have an interest in the submitted work. Other relationships: All authors have declared that there are no other relationships or activities that could appear to have influenced the submitted work.

\section{References}

1. Lopez-Jimenez F, Sert Kuniyoshi FH, Gami A, Somers VK: Obstructive sleep apnea: implications for cardiac and vascular disease. Chest. 2008, 133:793-804. 10.1378/chest.07-0800

2. Hales CM, Carroll MD, Fryar CD, Ogden CL: Prevalence of obesity and severe obesity among adults: United States, 2017-2018. NCHS Data Brief. 2020, 360:1-8

3. Peppard PE, Young T, Barnet JH, Palta M, Hagen EW, Hla KM: Increased prevalence of sleep-disordered breathing in adults. Am J Epidemiol. 2013, 177:1006-1014. 10.1093/aje/kws342

4. Strausz S, Havulinna AS, Tuomi T, et al.: Obstructive sleep apnoea and the risk for coronary heart disease and type 2 diabetes: a longitudinal population-based study in Finland. BMJ Open. 2018, 8:e022752. 10.1136/bmjopen-2018-022752

5. Jin S, Jiang S, Hu A: Association between obstructive sleep apnea and non-alcoholic fatty liver disease: a systematic review and meta-analysis. Sleep Breath. 2018, 22:841-851. 10.1007/s11325-018-1625-7

6. Patel N, Donahue C, Shenoy A, Patel A, El-Sherif N: Obstructive sleep apnea and arrhythmia: a systemic review. Int J Cardiol. 2017, 228:967-970. 10.1016/j.ijcard.2016.11.137

7. American College of Cardiology: cover story - impact and consequences of atrial fibrillation . (2018). Accessed: July 24, 2020: https://www.acc.org/latest-in-cardiology/articles/2018/08/06/12/42/cover-storyimpact-and-consequences-of-atrial-fibr....

8. Chugh SS, Havmoeller R, Narayanan K, et al.: Worldwide epidemiology of atrial fibrillation: a Global Burden of Disease 2010 study. Circulation. 2014, 129:837-847. 10.1161/CIRCULATIONAHA.113.005119

9. Benjamin EJ, Muntner P, Alonso A, et al.: Heart Disease and Stroke Statistics-2019 update: a report from the American Heart Association. Circulation. 2019, 139:e56-e528. 10.1161/CIR.0000000000000659

10. Linz D, McEvoy RD, Cowie MR, et al.: Associations of obstructive sleep apnea with atrial fibrillation and continuous positive airway pressure treatment: a review. JAMA Cardiol. 2018, 3:532-540. 10.1001/jamacardio.2018.0095

11. Mehra R, Benjamin EJ, Shahar E, et al.: Association of nocturnal arrhythmias with sleep-disordered breathing: The Sleep Heart Health Study. Am J Respir Crit Care Med. 2006, 173:910-916. 10.1164/rccm.200509-14420C

12. Gami AS, Hodge DO, Herges RM, Olson EJ, Nykodym J, Kara T, Somers VK: Obstructive sleep apnea, obesity, and the risk of incident atrial fibrillation. J Am Coll Cardiol. 2007, 49:565-571. 10.1016/j.jacc.2006.08.060

13. Youssef I, Kamran H, Yacoub M, et al.: Obstructive sleep apnea as a risk factor for atrial fibrillation: a metaanalysis. J Sleep Disord Ther. 2018, 7:282. 10.4172/2167-0277.1000282

14. Dalgaard F, North R, Pieper K, et al.: Risk of major cardiovascular and neurologic events with obstructive sleep apnea among patients with atrial fibrillation. Am Heart J. 2020, 223:65-71. 10.1016/i.ahj.2020.01.00

15. Gami AS, Pressman G, Caples SM, et al.: Association of atrial fibrillation and obstructive sleep apnea . Circulation. 2004, 110:364-367. 10.1161/01.CIR.0000136587.68725.8E

16. Guilleminault C, Connolly SJ, Winkle RA: Cardiac arrhythmia and conduction disturbances during sleep in 400 patients with sleep apnea syndrome. Am J Cardiol. 1983, 52:490-494. 10.1016/0002-9149(83)90013-9

17. Becker HF, Koehler U, Stammnitz A, Peter JH: Heart block in patients with sleep apnoea. Thorax. 1998 53:S29-S32. 10.1136/thx.53.2008.s29

18. Koehler U, Fus E, Grimm W, Pankow W, Schäfer H, Stammnitz A, Peter JH: Heart block in patients with obstructive sleep apnoea: pathogenetic factors and effects of treatment. Eur Respir J. 1998, 11:434-439. 10.1183/09031936.98.11020434

19. Gami AS, Olson EJ, Shen WK, et al.: Obstructive sleep apnea and the risk of sudden cardiac death: a longitudinal study of 10,701 adults. J Am Coll Cardiol. 2013, 62:610-616. 10.1016/j.jacc.2013.04.080

20. American Academy of Sleep Medicine: AASM clarifies hypopnea scoring criteria . (2013). Accessed: July 24, 2020: https://aasm.org/aasm-clarifies-hypopnea-scoring-criteria/.

21. Di Fusco SA, Pignalberi C, Santini L, Colivicchi F, Santini M: Arrhythmias and sleep apnea: physiopathologic link and clinical implications. J Interv Card Electrophysiol. 2020, 57:387-397. 10.1007/s10840-020-00707-'

22. Bayram NA, Çiftçi B, Güven FS, et al.: Prevalence of cardiac arrhythmia in obstructive sleep apnea syndrome. Turk J Med Sci. 2010, 40:843-850. 10.3906/sag-0910-355

23. Mehra R, Redline S: Sleep apnea: a proinflammatory disorder that coaggregates with obesity . J Allergy Clin Immunol. 2008, 121:1096-1102. 10.1016/j.jaci.2008.04.002

24. Van Wagoner DR: Oxidative stress and inflammation in atrial fibrillation: role in pathogenesis and potential as a therapeutic target. J Cardiovasc Pharmacol. 2008, 52:306-313. 10.1097/FJC.0b013e31817f9398 
25. Somers VK, Abboud FM: Chemoreflexes--responses, interactions and implications for sleep apnea. Sleep. 1993, 16:S30-S33.

26. Dempsey JA, Veasey SC, Morgan BJ, O'Donnell CP: Pathophysiology of sleep apnea. Physiol Rev. 2010, 90:47-112. 10.1152/physrev.00043.2008

27. Todd K, McIntyre WF, Baranchuk A: Obstructive sleep apnea and atrial fibrillation. Nat Sci Sleep. 2010, 2:39-45. 10.2147/nss.s7625

28. Shukla A, Aizer A, Holmes D, et al.: Effect of obstructive sleep apnea treatment on atrial fibrillation recurrence: a meta-analysis. JACC Clin Electrophysiol. 2015, 1:41-51. 10.1016/j.jacep.2015.02.014

29. Qureshi WT, Nasir UB, Alqalyoobi S, et al.: Meta-analysis of continuous positive airway pressure as a therapy of atrial fibrillation in obstructive sleep apnea. Am J Cardiol. 2015, 116:1767-1773. 10.1016/j.amjcard.2015.08.046

30. Li L, Wang ZW, Li J, et al.: Efficacy of catheter ablation of atrial fibrillation in patients with obstructive sleep apnoea with and without continuous positive airway pressure treatment: a meta-analysis of observational studies. Europace. 2014, 16:1309-1314. 10.1093/europace/euu066

31. Virk JS, Kotecha B: When continuous positive airway pressure (CPAP) fails . J Thorac Dis. 2016, 8:E1112E1121. 10.21037/jtd.2016.09.67

32. Pavwoski P, Shelgikar AV: Treatment options for obstructive sleep apnea. Neurol Clin Pract. 2017, 7:77-85. 10.1212/CPJ.0000000000000320

33. Feng TR, White RS, Ma X, Askin G, Pryor KO: The effect of obstructive sleep apnea on readmissions and atrial fibrillation after cardiac surgery. J Clin Anesth. 2019, 56:17-23. 10.1016/j.jclinane.2019.01.011

34. Holmqvist F, Guan N, Zhu Z, et al.: Impact of obstructive sleep apnea and continuous positive airway pressure therapy on outcomes in patients with atrial fibrillation-results from the Outcomes Registry for Better Informed Treatment of Atrial Fibrillation (ORBIT-AF). Am Heart J. 2015, 169:647-654. 10.1016/j.ahj.2014.12.024

35. Ng CY, Liu T, Shehata M, Stevens S, Chugh SS, Wang X: Meta-analysis of obstructive sleep apnea as predictor of atrial fibrillation recurrence after catheter ablation. Am J Cardiol. 2011, 108:47-51. 10.1016/j.amjcard.2011.02.343

36. Porthan KM, Melin JH, Kupila JT, Venho KK, Partinen MM: Prevalence of sleep apnea syndrome in lone atrial fibrillation: a case-control study. Chest. 2004, 125:879-885. 10.1378/chest.125.3.879

37. Javaheri S, Parker TJ, Liming JD, Corbett WS, Nishiyama H, Wexler L, Roselle GA: Sleep apnea in 81 ambulatory male patients with stable heart failure. Types and their prevalences, consequences, and presentations. Circulation. 1998, 97:2154-2159. 10.1161/01.cir.97.21.2154

38. Flemons WW, Remmers JE, Gillis AM: Sleep apnea and cardiac arrhythmias. Is there a relationship? . Am Rev Respir Dis. 1993, 148:618-621. 10.1164/ajrccm/148.3.618

39. Simantirakis EN, Schiza SI, Marketou ME, et al.: Severe bradyarrhythmias in patients with sleep apnoea: the effect of continuous positive airway pressure treatment: a long-term evaluation using an insertable loop recorder. Eur Heart J. 2004, 25:1070-1076. 10.1016/j.ehj.2004.04.017

40. Garrigue S, Pépin JL, Defaye P, Murgatroyd F, Poezevara Y, Clémenty J, Lévy P: High prevalence of sleep apnea syndrome in patients with long-term pacing: the European Multicenter Polysomnographic Study. Circulation. 2007, 115:1703-1709. 10.1161/CIRCULATIONAHA.106.659706

41. Steiner S, Schueller PO, Hennersdorf MG, Strauer BE: Obstructive sleep apnea in heart failure patients: evidence for persistent conduction disturbances or sinus node dysfunction. J Physiol Pharmacol. 2008, 59:669-674.

42. Gami AS, Howard DE, Olson EJ, Somers VK: Day-night pattern of sudden death in obstructive sleep apnea . N Engl J Med. 2005, 352:1206-1214. 10.1056/NEJMoa041832

43. Becker H, Brandenburg U, Peter JH, Von Wichert P: Reversal of sinus arrest and atrioventricular conduction block in patients with sleep apnea during nasal continuous positive airway pressure. Am J Respir Crit Care Med. 1995, 151:215-218. 10.1164/ajrccm.151.1.7812557

44. Harbison J, O'Reilly P, McNicholas WT: Cardiac rhythm disturbances in the obstructive sleep apnea syndrome: effects of nasal continuous positive airway pressure therapy. Chest. 2000, 118:591-595. 10.1378/chest.118.3.591

45. Kanagala R, Murali NS, Friedman PA, et al.: Obstructive sleep apnea and the recurrence of atrial fibrillation. Circulation. 2003, 107:2589-2594. 10.1161/01.CIR.0000068337.25994.21

46. Marin JM, Carrizo SJ, Vicente E, Agusti AG: Long-term cardiovascular outcomes in men with obstructive sleep apnoea-hypopnoea with or without treatment with continuous positive airway pressure: an observational study. Lancet. 2005, 365:1046-1053. 10.1016/S0140-6736(05)71141-7

47. Wu X, Liu Z, Chang SC, et al.: Screening and managing obstructive sleep apnoea in nocturnal heart block patients: an observational study. Respir Res. 2016, 17:16. 10.1186/s12931-016-0333-8 